\title{
Sinema - Bilim - Felsefe Triyalektiği: Kuantumun Çoklu Referans Sistemi ve Sinematik Anlatıya Yansımaları
}

\author{
Ezgi Tokdil ${ }^{*}$
}

\section{Özet}

Makalede 20. yüzyıl ve devamında, mikro dünyanın tanımlanmasına yönelik ortaya konulan olağan bilimsel etkinlikler dönemini kapsayan kuantum fiziği ve onun evrenin tanımlanmasına getirdiği temel kuram ve ilkeler analiz edilerek, 1920'lerden itibaren deneysel film ve 20. yüzyıl sonlarından itibaren modern sinemaya yansımalarn incelenmektedir. Bu doğrultuda hem bilimsel gerçekliğin sinemaya konu bağlamında yansımaları (bilimin gelişimsel yönünün sinemanın anlatı biçimlerini değiştirmesi) ve teknolojik olanakların değişen dünyanın değiş̧en dilini sinematik felsefe bakımından etkilemesi hem de kuantum alanına ilişkin temel ilke ve söylemlerin sinematik düşünce ve/ya sinematik imge üzerindeki paralel söylem dilinin/ görüntü özelliklerinin incelenmesi amaçlanmaktadır. Bu paralel ilişkiyi tanımlamak ve anlamak adına örnekleme alınan filmler üzerinden karşılaştırmalı bir analiz gerçekleştirilerek, sinematik düşüncenin bilimsel aklı nasıl yorumladığı, söz konusu yorumlamanın hangi yöntemlerle yapıldığı, gerçeklik çizgisinin sinema felsefesinde hangi sınırda yer aldı̆̆̊ ve paradigma değiş̧iminin bütün olarak sinema-felsefe- bilim triyalektiğini nasıl yönlendirdiği analiz edilmektedir. Bilimsel gelişmenin ve kuantum alanına ilişkin temel ilke ve yaklaşımların sinema alanına yansımalarının örneklendirildiği filmler olarak; Lev Kuleshov, Vsevolod Pudovkin, David W. Griffith, Sergei Eisenstein ve Dziga Vertov'un montaj tekniğini kullandiğ filmler, Fernand Leger'in Dudley Murphy ile yönetmenliğini üstlendiği Ballet Mécanique (1924) filmi, Germaine Dulac'ın, Hans Richter'm, Man Ray ve Viking Eggeling'in deneysel sinema örnekleri, Duchamp' in sinema alanina katkıları, Jean-Luc Godard'in Breathless filmi (1960), Paul Thomas Anderson'in Magnolia filmi (1999), Butterfly Effect (2004), Another Earth, J. J. Abrams, Alex Kurtzman ve Roberto Orci tarafindan kurgulanan bilimkurgu dizisi Fringe (2008-2013) ve 1999 yapımı Matrix filmi ile 2014 yapımı Interstaller incelenmektedir. Bu filmlerde yer alan gerçeklik yaklaşımı; 20. yüzyılın başlarından itibaren her alanda yaşanan büyük değişimlerin etkisinde Newtonsal kabullerden kurtulmuş ve göreli evren anlayışı ile çoklu referans sistemlerinde tanımlanabilen bir gerçekliğe adım atmış yeni bilincin ürünüdür.

Anahtar Sözcükler: Kuantum Alanı, Sinematografik Anlatı, Belirsizlik İlkesi, Deneysel Film, Modern Sinema

*ORCID: 0000-0003-2701-0842

E-Mail: ezgi.tokdil@gmail.com

DOI: $10.31122 /$ sinefilozofi.665793

Geliş Tarihi - Recieved: 10.01.2020

Kabul Tarihi - Accepted: 25.03.2020 


\title{
Cinema - Science - Philosophy Trialectics: Multiple Reference System of Quantum and its Reflections on Cinematic Narrative
}

\author{
Ezgi Tokdil ${ }^{*}$
}

\begin{abstract}
In this research, quantum physics, which covers the period of ordinary scientific activities about the definition of the micro world and its main theories and principles in the definition of the universe are analyzed by analyzing experimental film since the 1920s and its reflections on modern cinema since the end of the 20th century. In this respect, both the reflections of scientific reality in the context of cinema (the developmental aspect of science changes the narrative forms of cinema), the technological possibilities affect the changing language of the changing world in terms of cinematic philosophy, and the basic principles and discourses of the quantum field on the parallel discourse on cinematic thought and/or cinematic image. to examine the image properties. In order to define and understand this parallel relationship, a comparative analysis is performed on the films taken in order to understand how cinematic thought interprets the scientific mind, how the interpretation is made, the boundary of the real line in cinema philosophy and the paradigm shift as a whole. is being analyzed. Lev Kuleshov, Vsevolod Pudovkin, David W. Griffith, Sergei Eisenstein and Dziga Vertov use the montage technique, Ballet Mécanique (1924), directed by Fernand Leger and directed by Hans Richter, Man Ray and Viking Eggeling's experimental cinema examples, Duchamp's contributions to cinema, Jean-Luc Godard's Breathless (1960), Paul Thomas Anderson's Magnolia (1999), Butterfly Effect (2004), Another Earth, JJ Abrams, Alex Kurtzman and Roberto Orci's science fiction series Fringe (2008-2013) and the 1999 film Matrix and the 2014 Interstaller are considered as films that illustrate the reflections of scientific development and the fundamental principles and approaches of quantum to the cinema. The reality approach in these films is; It is the product of a new consciousness that has been freed from Newtonian assumptions under the influence of the great changes in every field since the beginning of the 20th century and has stepped into a reality that can be defined in multiple reference systems with relative universe understanding.
\end{abstract}

Keywords: Quantum Field, Cinematographic Narrative, Uncertainty Principle, Experimental Film, Modern Cinema

*ORCID: 0000-0003-2701-0842

E-Mail: ezgi.tokdil@gmail.com

DOI: 10.31122/sinefilozofi.665793

Received - Geliş Tarihi: 10.01.2020

Accepted - Kabul Tarihi: 25.03.2020 


\section{Giriş}

Paradigma değişimleri hangi alanda gerçekleşirse gerçekleşsin, diğer tüm alanlarda önemli değişimlere neden olur ve köklü bir yeniden biçimlendirmeyi beraberinde getirir. Bununla birlikte eski paradigmanın temel kavramları da yeni anlamlar yüklenir, yeni anlam örüntüleri ortaya çıkar. Paradigmatik bilim tarihine bakıldığında her yeni paradigmanın kendinden önceki paradigma kapsamında gerçekleşen olağan bilim etkinliklerinde yaşanan belirli bunalımların ardından ortaya çıktığı, bu bunalımlara neden olan düğüm noktalarının çözümüne ilişkin yeni ilke ve yasaların olduğu, bununla birlikte eski paradigmaya ait temel olgusal gerçekliklerin referans çerçevesinin değiştiği, buna paralel eskinin kavram ve tanımlamalarının da bu çerçeve kapsamında yerini yeni açıklamalara bıraktığı görülmektedir. Örneğin Kopernik devrimi Aristoteles fiziği üzerine temellenen ve merkezine dünyayı (dünya ile birlikte insanı) alan evren modelini ortadan kaldırarak, yerine güneşi yerleştirmiş ve dünyayla birlikte insana ilişkin tüm unsurlar ayrıcalıklı konumundan indirilmiş, evrensel bir düzenin olağan bir parçası haline gelmiştir (bu tıpkı dinin ve kilise baskısının aydınlanma düşüncesi ile birlikte etkisini yitirmesi gibi bir değişimdir). Darwin'in doğal seçilim kuramının da bu düşüncenin bir uzantısı olduğu görülür. Bir diğer örnek Newton'un mutlak zaman ve mutlak mekan düşüncesinin yerini alan Einstein'ın görelilik ilkesidir ve madde, uzay ve zaman kavramlarına ilişkin yeni bir çerçeve çizilmiş, bu çerçeve bilim adamlarının olduğu kadar felsefe alanının da gerçekliğe bakışını yeniden biçimlendirmiştir. Bu değişim aynı zamanda toplumsal, ekonomik, siyasi ve tek tek bireysel bakış açılarında da köklü bir değişimi beraberinde getirmiştir. Bunun sonucunda kültürel bakış açısı ve biçimlendirme anlayışları da söz konusu değişim ve ilerlemenin etkisinde yeni yaratı biçimlerine (teknolojik gelişmeye paralel) yönelmiştir. Kuantum fiziğinin göreli evren düşüncesi ile aynı yüzyılda ortaya çıkması da gerçekliğe bakış açılarında ve nedensellik düzleminde önemli ayrımları beraberinde getirmiş, bununla birlikte çoklu referans sistemlerinde tanımlanabilen bir gerçeklik yaratarak içinde yaşanılan yüzyılın algılama perspektiflerini bütünüyle değiştirmiştir.

\section{Paradigma Değişiminin Sinema-Bilim-Felsefe Triyalektiğine Etkisi}

Bu kapsamda sinema, bilim ve felsefe triyalektiğine bakıldığında; bilimsel ilerleme dönemlerinin her birinde referans çerçevesinin değiştiği, yaşanılan evrene ilişkin temel ilke ve söylemlerin yeni açıklama ve yaklaşımlara yerini bıraktığı görüldü. Bu doğrultuda toplumsal bir değişim söz konusudur ve bu değişimin temelleri de felsefenin düşünce biçimlerini şekillendirir. Ütopik bir evren düşüncesine paralel gerçekliği ve gücü tek bir elde toplayan ideal dünya tasarımı olan totalistik düşünce köklerini Platon'un idealar dünyasından alır ve Sokrates, Aristoteles gibi filozofların yaklaşımlarıyla şekillenir. Aristoteles fiziği ve Kopernik devrimine kadar olan süreçte bilimsel aklın gerçekliği yorumlama biçimi de benzer bir algıda ilerler. Bu dönemin kültürel kodları da aynı düşünsel temelden beslenir; sanat dinin etkisindedir (yaratıcı olarak tanrı ön plandadır), ideal güzellik anlayışı hakimdir (mitolojik konular ortaya çıar) ya da Ptolemi'nin dünya merkezli evren modelinde olduğu gibi olay ve olgular resmin ortasının aydınlatılması ile tek bir merkeze vurgu yapılarak resmedilir. Modernist düşüncenin temellerini ise Descartes atmıştır ve Kant, Hegel, Marx yeni paradigmanın önemli düşünürleri olarak tarihsel sürekliliği devam ettirirler. Bu düşüncenin temellendiği dönem aynı zamanda feodalist yönetim biçiminin kapitalizme evrildiği süreçle kesişir. Bununla birlikte bilimde de yeni bir paradigma kayması söz konusudur; Descartes'in düşünsel temelini oluşturduğu Newton'un yeni evren tasarımı. Newton'la birlikte bilimde nedensellik ilkesine ulaşılmış, gerçekliğin matematiksel formüllerle tanımlaması yapılmış ve Aristoteles fiziğinde tanımlanamayan pek çok olguya açılama getirilmiş, buna paralel eskinin madde, uzay, hareket (devinim), zaman 
kavramlarının anlamları yeniden şekillenmiştir. Ancak burada bilimsel gerçeklikle düşünce ve sanat arasında tarihsel olarak bir kayma yaşanır, bunun nedeni Newton fiziğinin her ne kadar bilimsel gerçekliği nedensellik temeline sokmuş olsa da kütleçekim gibi bazı temel ilkelerinin nedenini açılayamamasını tanrısal güce bağlamış olmasındandır. Bu düşünce sanatın da dinsel temalarını sürdürmesi ve ancak belirli temalar çerçevesinde günlük yaşam sahnelerine geçilebilmesi sonucunu doğurmuştur. Bireysel dişavurumlara (anlatımlara) ve modernist düşünceye paralel modernist biçimlendirme anlayışlarına geçiş (içerik bağlaminda değişimin) gecikmeli olarak Einstein fiziğinin çizdiği referans çerçevesinde mümkün olmuştur. Mobilist (postmodern) düşünce ise gene bilimde ve toplumsal yapıda yaşanan paradigmatik değişimle paralel gelişmiştir. Enformasyonalist toplumların kaygan ve değişken iktidar üçgeninin ve enformasyon odaklı yönetim biçiminin bilim tarihi ile kesişim noktasında Einstein'ın görelilik ilkesi ve kuantum alan teorisinin ortaya çıkması yer alır. Görelilik ilkesinin evrene ilişkin soyut algılama perspektifleri ve kuantumun çoklu referans noktaları, postmodern düşüncenin de benzer yönde şekillenmesine neden olmuştur. Bu yeni dönem Nietzsche, Deleuze ve Foucault gibi düşünürlerin öncülüğünde başlamış, Wittgenstein ve Sartre gibi düşünürlerle devam etmiştir. Genel olarak bakıldı̆̆ında referans noktasının somut kavram ve yaklaşımlardan (kabul görmüş ortak değerler), soyut düşünce ve değişken olgulara doğru olduğu görülmektedir.

Sinema tarihine bakıldığında da her ne kadar geleneksel sinemanın başlangıcı 1895 yılına tarihlense de (Fransız Lumiere kardeşler) bu yönde atılan ilk adım (icat) Camera Obscura'dır (karanlık oda) ve bir kutuya açılan bir delikten tutulan bir cismin kutunun diğer tarafına yansıması şeklinde çalışır. Felsefi açıdan Platon'un ünlü mağara alegorisini anımsatan bu yaklaşım giderek gerçeğin temsiline, ardından gerçeğin kendisine dönüşmüş ve bu süreç yukarıda incelenen farklı alanlarda yaşanan ilerlemelere koşut gelişmiştir. Kıraç'ın ifade ettiği gibi (2012: 19); "sinemanın keşfinin dünyadaki teknolojik gelişmelerle doğrudan ilişkisi vardır", ancak teknolojinin yaratılmasında geri planda bilimsel gelişmeler, toplumsal dinamikler, kültürel politikalar ve siyasi ideolojiler rol oynamaktadır. Bununla birlikte değişim gene farklı alanların ortak duyumunda gerçekleşmiştir. Kopernik devriminin dünyayı evrenin merkezinden indirip, evrensel düzen içinde diğer gezegenlerle eşit konuma taşıması, Darwin'in insanı diğer canlılardan ayıran nitelikleri ortadan kaldırarak ayrıcalıklı konumundan indirmesi gibi fotoğraf ve sinema teknolojileri de giderek bireye yüklenen bu merkezi konumun geri plana atılmasına neden olmuştur. Örneğin John Berger'e göre; "perspektifle yapılmış her taslak ya da yağlıboya resim, seyirciye dünyanın biricik merkezinin kendisi olduğunu söylüyordu" (1993: 6). Ancak devam eden süreçte önce fotoğraf makinesinin ardından sinema makinesinin ortaya çıkması ile -Berger'e göre sinema makinesinin etkisi fotoğraftan daha fazladır- resimsel anlatımdaki izleyiciye yüklenen merkezi biriciklik ortadan kalkmıştır (Berger, 1993: 6). Bu aynı zamanda yukarıda tanımlandığ1 gibi, toplumsal sistemlerde kapitalist paradigma ve bilimsel gelişmede Newton sonrası olağan bilim etkinlikleri ile bağlantılı bir ilerlemedir. Bununla birlikte kültür alanında ve özellikle sanat akımlarında yaşanan değişimler de sinemanın dilini önemli ölçüde değiştirmiştir. Örneğin 1920'lerde sanat alanında yaşanan avangard devrim sinema alanında da önemli değişimlere neden olmuştur. Bu dönemde görsel sanatlar alanında çalışmalar üreten sanatçılar avangard biçimlendirme anlayışlarını ve düşünme biçimlerini sinema alanına uygulamanın yollarını aramıştır. Başka bir yaklaşımla söz konusu devrim, sanatçıya ve film yapımcısına farklı bakış açıları ve uygulama deneyimleri sunmuştur. Bu dönemde Fernand Leger, Hans Richter, Man Ray, Viking Eggeling, Marcel Duchamp, Rebert Wiene, Oscar Fischenger vd. gibi görsel sanatlar alanında çalışan sanatçılar sinema alanında deneysel çalışmalar yapmışlardır. 
Devam eden tarihsel süreçte tıpkı Kopernik'in dünyayı evrenin merkezinden indirmesi, Descartes'in madde ve uzayı birleştirerek evreni tanımlama girişimleri ve Newton'un bu olguları ayırarak mutlak uzay ve mutlak zaman düşüncesini formülleştirmesi ve en sonunda Einstein'ın zaman-mekanı bir araya getirmesi gibi, fotoğrafın keşfinin ardından sinema alanında yaşanan ilerleme de benzer bir süreçte gelişmiştir. Sinema tarihine bakıldığında da zaman ve devinimine ilişkin arka arkaya çekilen fotoğraf karelerinin birleştirilmesi ile hareketli görüntülerin elde edildiği görülmektedir. Bu aynı zamanda yukarıda adı geçen sanatçıların çizimlerinin hareketlendirilmesi gibi bir kurgusal gerçekliğe sahiptir.

\section{Kuantum Fiziği ve Evrenin Tanımlanmasına İlişkin Temel İlke ve Söylemler}

Kuantum fiziği en temel anlamda moleküler, atom ve atomaltı dünyanın, madde ve enerjinin davranışını ve doğasını açıklamaya çalışan modern fiziğin bir alanıdır. Ancak Einstein'ın görelilik ilkesinin ardından evrenin tanımlanmasına ilişkin getirdiği yeni bakış açıları ve bilimsel kuramlar onun başı başına fizik alanında bir paradigma olarak kabul görmesine neden olmuştur. Bununla birlikte kuantum fiziğinin kapsamı içine yalnızca mikro dünyanın alışılmış atom altı parçacıkları değil makro evrene ilişkin temel yasa va açıklamalar da girer. Klein'e göre bunun nedeni; "kuantum yasalarının, bizi çevreleyen süreçler ya da cisimlerin özellikleri ve niteliklerini geri planda, neredeyse gizli bir şekilde yönetiyor olmasıdır" (2018: 13). Bu yönetme özünde yaşama ilişkin tüm değerlerin de yıkılması ve yerlerini yeni kavram ve açıklamalara bırakması ile gerçekleşmiştir. Bununla birlikte bu değişim Klein'e göre; "bizzat gerçek kavramının kendisinin" tartışılmasına neden olmuştur; "mikroskobik ölçekte şeylerin gerçekliği artık besbelli değildir (...)" (2018: 14).

Kuantum mekaniğinin (fiziğinin) tarihsel gelişimine bakıldığında; öncelikle 1900 yılında Max Planck tarafından makro evrenin tanımlanmasında kullanılan kara cisim ışıması özelliğinin açıklanmasında "kuantumlanmış enerji yayılımı"nı kullanılması kuantum fiziğinin başlangıcı olarak kabul edilmiştir. 1905 yılında Einstein'ın fotoelektrik kuramı (1şı̆̆ın dalga özelliğinin yanında belirli büyüklüğe sahip enerji paketlerinden -fotonlaroluştuğunu iddia etmesi) gerçekleşmiştir. 1911'de Rutherford'un atomun çekirdek modelini oluşturması ve 1913'de Niels Bohr tarafından atom spektrumunun açıklanması (atomun gezegen sistemi gibi betimlenmesi) devam eden süreçte kuantum mekaniğinin gelişiminde rol oynayan önemli bilimsel gelişmelerdir. 1923'te Arthur Compton X- 1şınları ile elektronların etkileşiminden ışığın parçacık davranışı ile ilgili yeni kanıtlara ulaşmış, Louis de Broglie 1şı̆̆ın dalga-parçacık ikilemini genelleştirmiştir. 1925'te Heisenberg'in belirsizlik ilkesi, parçacıkların konum ve momentumlarının aynı anda tam olarak belirlenemeyeceğini öne sürmüş, 1926'da Erwin Schrödinger tarafından dalga denklemi ortaya atılmıştır. 1935 yılında Einstein, Podovsky ve Rosen tarafından EPR Paradoksu olarak bilinen kuantum dolanıklık (iki parçacığın geniş mesafelerde birbirlerini etkilemesi ve eşdeğer davranış sergilemesi özelliği) kuramı geliştirilmiş, aynı yıl Schrödinger tarafından eleştirilen EPR paradoksunun ardından öne sürülen düşünce deneyi (bir kutuya yer alan bir kedinin ölü ya da canlı olma durumu), belirsizlik ilkesine paralel (gözlenen olgu ölçülene dek belirsizdir ve iki olasılıktan birine sahiptir) ancak gözlem yapıldığında her iki olasılıktan birinin geçerli olacağını öne sürer. Devam eden süreçte Niels Bohr'un Kopenhag yorumuyla bağlantılı olarak çoklu evren teorisi ortaya çıkmış ve Stephen Hawking, Richard Feynman gibi bilim adamları tarafından desteklenmiştir.

Bütün olarak kuantum fiziğinin kendinden önceki bilimsel paradigmalardan ayrılan yönünün, gerçekliğin referans çerçevelerinin çoklu alg1 perspektiflerine sahip olması, karmaşık ve olgusal düzeyde bilimsel bilginin tanımlanmasında yalnızca formalist değil aynı 
zamanda fiziksel bir yoruma yer veriyor olması, bunun yanında gerçekleştirilen her eylemin olgu-karşı olgu diyalektiğini bütünüyle ele alıyor ve ayrıştırılamaz doğasını tamamlayıcı nitelikleriyle değerlendiriyor olmasından kaynaklandığı görülür. Bununla birlikte Klein'e göre; "kuantum fiziğinin etkisi bilişsel veya açılayıcı alanın çok ötesine gider" (2018: 13). Gerek teorik fizik alanında gerekse uygulamada kapsam ve sınırları, mikro ve makro gerçeklik dünyasında olduğu gibi kapsamlı ve geniştir.

\section{Sinematik Düşüncenin Bilimsel Aklı Yorumlama Biçimi}

Yukarıda tarihsel gelişim aşamaları ve genel çerçevede tanımlamaları verilen kuantum alanına ilişkin temel kavram ve ilkelerin sinematik düşünceye yansımaları bu bölümde ayrıntılı olarak ele alınmaktadır. Bu karşılıklı ilişki incelenirken öncelikle 20. yüzyılın başlarından itibaren montaj tekniğinin kullanıldığı filmler üzerinde kuantum alanına ilişkin bilimsel gerçekliklerin yorumsal analizi yapılmakta, ardından aynı başlık altında avangard sinemanın öncüleri hem görsel sanatlar alanında ürettikleri çalışmalarla hem de sinema alanındaki deneysel film örnekleriyle paradigmatik değişim açısından sinema-bilim-felsefe triyalektiğinde analiz edilmektedir. Araştırmanın devamında sinema felsefesi bakımından kuantum fiziğinin temel kavramlarının nasıl yorumlandığı (bilimsel gerçekliğin sinemaya tematik yansıması) örnekleme alınan filmler üzerinden incelenmektedir.

$\mathrm{Bu}$ kapsamda değerlendirildiğinde kuantum fiziğinin görsel sanatlar ve özelde sinema alanına yansımaları belirli başlıklar altında toplanabilir. Bunlardan ilki kuantum fiziğinin felsefi alt yapısından ve temel ilkelerinden yola çıkılarak / esinlenilerek üretilen çalışmalardır, ikincisi doğrudan değil ancak alımlayıcının bu ilişkiyi dolaylı olarak kurduğu/kurabildiği deneysel filmlerdir, üçüncüsü kuantumun tanımlamış olduğu yeni gerçekliğin ve teknoloji boyutunda sanata yansımalarının sinemanın konusu olduğu filmlerdir.

\section{Kuantum Alanının Sinematik Düşünceye Yansıması}

Kuantum alanının (kuantum fiziğinin) sinematik düşünceye yansımalarına bakıldığında öncelikle 1920'lerden itibaren montaj tekniğinin gelişimi ile Lev Kuleshov, Dziga Vertov, Vsevolod Pudovkin, David W. Griffith ve Sergei Eisenstein gibi film yapımcılarının zaman vurgusunu ön plana çıkardıkları görülmektedir. Bu film yapımcıları her bir görüntünün bir dizi çekimin sentezinden oluştuğunu savunan kuramcılardır (Bordwell, 1972: 10; Tokdil, 2018: 176-77). Joyce'a göre (2003: 394); "Montaj tekniği, iki farklı görüntünün yan yana yerleştirildiğinde izleyicinin bu parçaların kaçınılmaz olarak ilişkili olduğu sonucunu çıkardığı teorisine dayanır". 20. yüzyılın ilk yarısından itibaren montaj tekniği; "bir anlatı (yapay bir zaman ve mekan oluşturarak veya izleyicinin dikkatini bir anlatı noktasından diğerine yönlendirerek), ritmi kontrol etmek, metafor yaratmak ve retorik noktaları oluşturmak için kullanılmıştır" (Bordwell, 1972: 9). Bu yaklaşım Einstein'ın zaman ve mekana ilişkin göreli evren anlayışından, Bohr'un tamamlayıcılık ilkesine ve hatta Schrödinger'in düşünce deneyinin süperpozisyon ve olasılık dalgasına kadar bilimsel gelişmelerin ve kuantuma ilişkin temel söylemlerin gözlemlenebildiği çoklu bir referans çerçevesi sunar.

Bu kapsamda öncelikle Kuleshov'un 1918 yapımı Engineer Prite's Project filmine bakıldığında (Görsel 1-2) farklı imgelerin (bekleyen bir kadın, yürüyen bir adam, bir merdiven, bir kapı, bir ev vd.) farklı sahnelerde çekilip bir araya getirildiği ve tek bir filmde bu sahneler birleştirildiğinde izleyicinin algısal olarak ilişkili olmayan figür ve nesneleri aynı anda varmış gibi hissettikleri bir kurgusal gerçeklik yaratıldığı görülmektedir (Joyce, 2003: 
359; Tokdil, 2018). Kuleshov etkisi olarak bilinen bu yaklaşım; "her görünür planın bir diğerini etkilediğini ve algılanma sürecini değiştirdiğini" ifade eder. Gerçekliğin yansıtılmasında aynı algısal yaklaşım Pudovkin, Eisenstein ve Hitchcock filmlerinde de görülmektedir (Tokdil, 2018: 178).
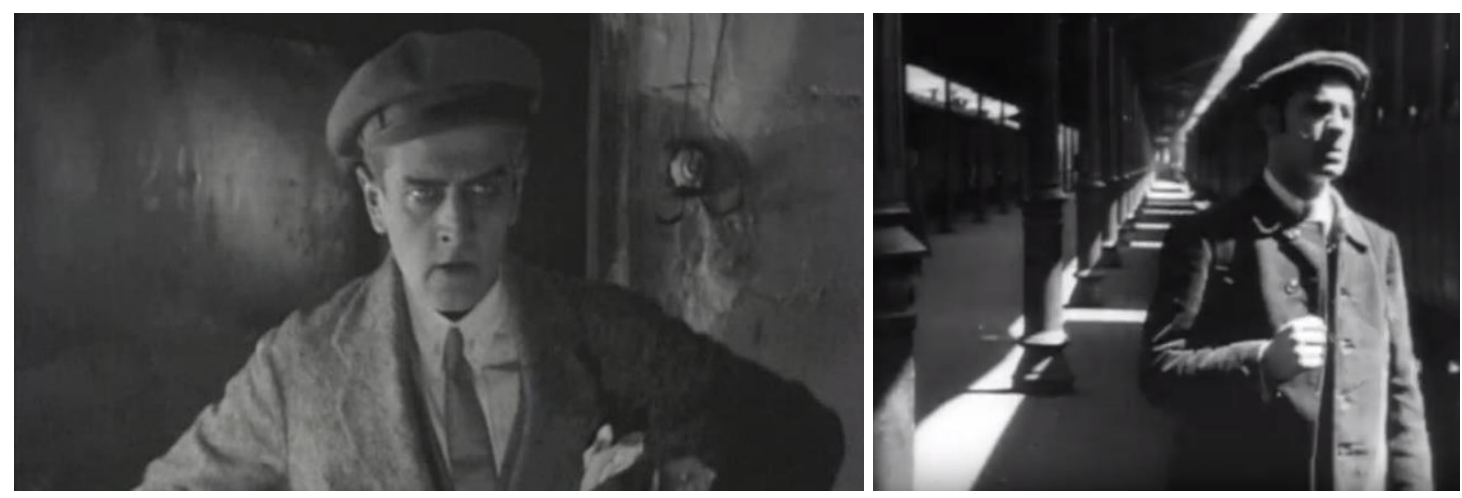

Görsel 1-2. Lev Kuleshov, Engineer Prite's Project (1918)

Kuleshov etkisinin karşılığı psikolojide gestalt teorisi olarak bilinir ve yalnızca bir parçası ya da bütüne ilişkin bir boyut tanımlandığında insanın o nesnenin geri kalan parçasını algısal olarak tamamlayabileceği savunusunu yapar. Bilimsel gerçeklik (kuantum alanı) açısından bakıldığında gerek Kuleshov filmlerinde gerekse montaj tekniğini kullanan diğer film yapımcılarının çalışmalarında yer alan bu yaklaşım, Bohr'un tamamlayıcılık ilkesi ile paralel bir yoruma sahiptir. Bu aynı zamanda montaj tekniğinin kullanıldığı tüm çalışmalar için geçerli bir yaklaşımdır; bu yaklaşıma göre (kuantum fiziği dahilinde) farklı deneysel koşullar altında elde edilen veriler tek bir tamamlanmış resimle açıklanamaz, çoklu veriler bir araya getirilmelidir, yani bir fenomenin tam ve güvenilir olarak tanımlanabilmesi için olası farklı koşulların her birinin ayrı ayrı ölçülmesi gerekir. Öyleyse montaj tekniğinin ayrı ayrı elde edilmiş her bir görsel veriyi bir araya getirerek elde etmiş olduğu hareketli görüntülerle benzer bir analojiye sahiptir. Bununla birlikte Kuleshov'un Engineer Prite's Project (1918) filminde kuantum alanına ilişkin Kopenhag yorumuna da ulaşılır. Kuantum mekaniğinin klasik fizikten ayrılan yönü olan bilincin rolünü öne çıkaran (gözlemci etkisi) yaklaşım, "fenomenin doğasının gözlem sonucunda var olduğu ve gözlem olmadan farklı olasılıkların süperpozisyonu (Schrödinger'in kedisi deneyinde olduğu gibi) konumunda olduğu görüşünün" birebir yansımasına dönüşür. Öyleyse birbiriyle ilişkili olmayan farklı imgeler arka arkaya getirildiğinde izleyici (gözlemci) tarafından birbirleriyle ilişkilendirildiğinde süperpozisyon çöker ve farklı olasılıklardan birine indirgenir (örn. bir adam ve yürüyen bir kadın ilişkilendirildiğinde zaman ve mekan olarak bilinç tarafından birbirlerine doğru konumlandırılır). Böylelikle devam eden bir sürekliliğin, zamansal bir gerçekliğin yansımasına dönüşür.

Aynı etki Dziga Vertov'un 1929 yapımı Man with a Movie Camera filminde de vurgulanır (Görsel 3-4). Dziga Vertov'un avangard sinemanın öncülerinden sayılan bu yapımında kameralı bir adamın sosyalist Rusya'da geçen bir günü anlatılmaktadır. Özcan'ın aktarımıyla bu bir gün içerisinde; "hayatın hemen her noktası, insanın her hali, uç uca eklenmiş bir kaç saniyeden oluşan sekanslarla bu merceğe yansır" (2016: 6). Fütürist sanatın temel manifestosunun etkileri burada da başroldedir. İnsan ve makinenin sırasıyla başrolleri paylaştığı yapımda bu iki unsurun birbirinden nasıl etkilendiği, toplum hayatına giren makineleşme sürecinin sosyalizm ideolojisinin perspektifinde gündelik yaşantıya nasıl yansıdığı birbiri üzerine montaj tekniği ile yerleştirilmiş görüntüler yoluyla izleyiciye aktarılmaktadır (Özcan, 2016: 6). 

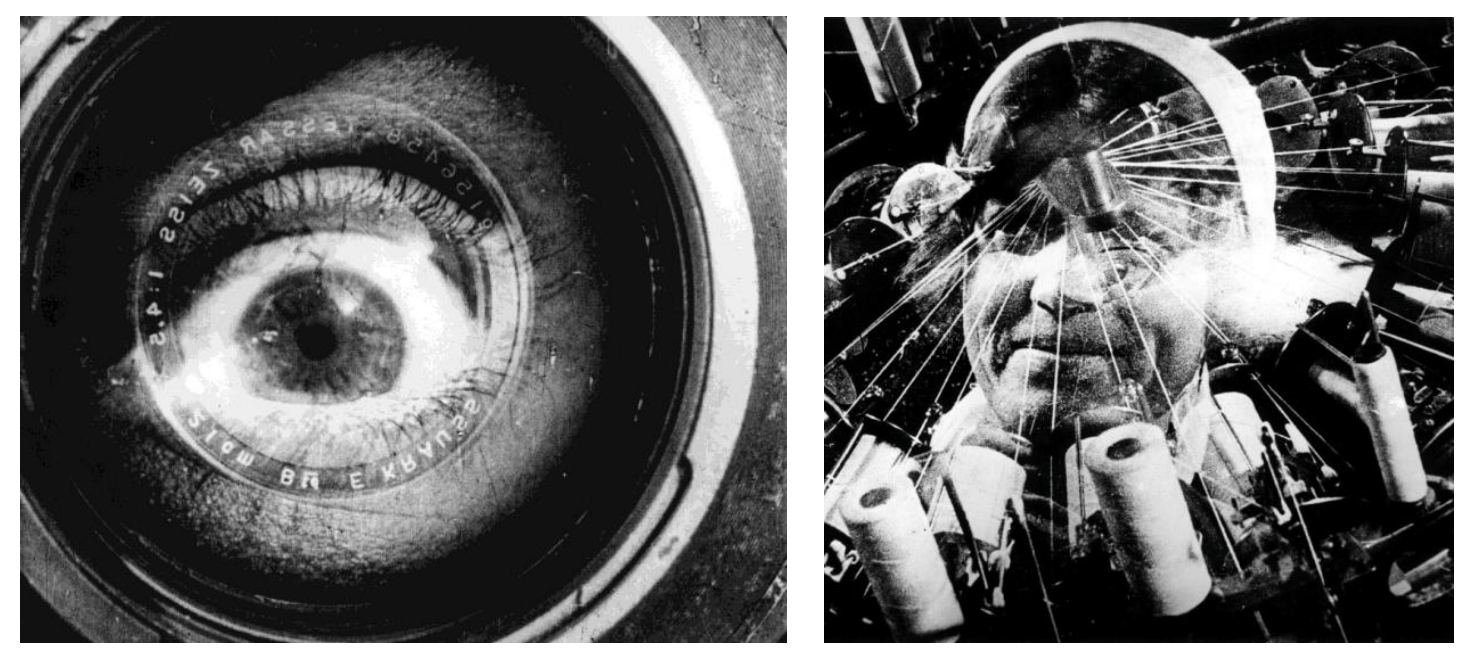

Görsel 3-4. Dziga Vertov, Man with a Movie Camera (1929)

Burada da gene birbirleriyle ilişkisiz farklı imgeler ve farklı sahneler bir araya getirilir ve bu kez Kuleshov'un montaj tekniğinden farklı olarak zamansal montaj tekniği ile üst üste yerleştirilir. Burada gene bilincin algılama kapasitesi devreye girer ve farklı sahneleri aynı anda okuyan (gören) zihin ekrandan yansıyan görüntünün daha hızlı akmasını deneyimler. Manovich'e göre (2002: 9); "çekimler bir araya getirilerek zamansal verimlilik sağlanır, ancak bu yaklaşım izleyicinin bilişsel sınırlarını zorlar. Üst üste bindirilmiş görüntüleri okumak zordur ve bilgi gürültü haline dönüşmektedir" (Tokdil, 2018: 177). Bu teknik aynı zamanda 1920'lerin Rus yapısalcılarının kullandıkları fotomontaj tekniğinin sinema alanındaki karşılığıdır. Bilimsel gerçeklik açısından gene Bohr'un tamamlayıcılık ilkesinin temel söylemine ve Einstein'ın zamansal dördüncü boyutunun görüntü estetiğine ulaşllabilir. Söz konusu montaj tekniği aynı zamanda Kandinsky ve diğerlerinin nesnel gerçekliği atom benzeri basit geometrik formlara indirgeyip resim düzleminde rastgele yeniden düzenlemesine benzer bir biçimlendirme anlayışıdır. Benzer şekilde her bir görüntü karesinin de atom ya da atom-altı parçalar benzeri bir görünüme sahip oldukları ve bir araya geldiklerinde devinime (imgenin hareketine) ve maddeye (ilişkinin doğasına) gönderme yaptıkları görülür. Örneğin bir kamera merceği ile bir göz imgesi farklı sekanslarda çekilip üst üste yerleştirildiğinde gerçekliğin kendisi ile onu gözleyen arasındaki mesafe ortadan kalkar, bu bir anlamda Bohr'un "bir fenomenin farklı olası bazları" olarak adlandırdığı eylemin çekme ve çekilme anlarının bir araya getirilmesi ile tamamlayıcılık ilkesinin sinema alanına yansımasıdır. Bununla birlikte Heisenberg'in belirsizlik ilkesi kapsamında fenomenin bir özelliği ne kadar doğru ölçülürse tamamlayıcı özelliğinin doğru olarak ölçümü o kadar az geçerli olur. Vertov sineması üzerinden bu açıklamaya bakıldığında örneğin ekrana yansitılan üst üste yerleştirilmiş iki veya daha fazla görüntüden herhangi biri daha belirgin hale gelirse onu tamamlayan diğer görüntünün okunabilirliği o kadar azalır. 


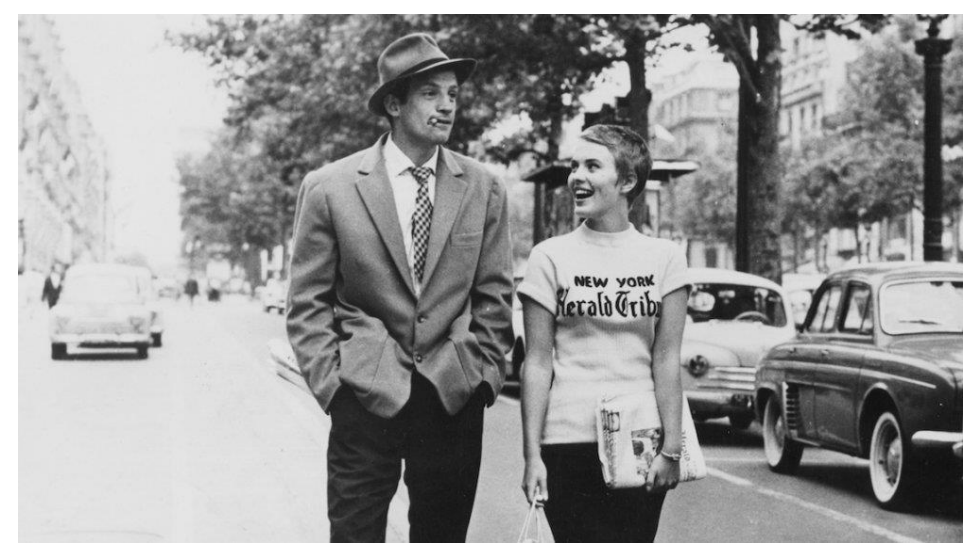

Görsel 5. Jean-Luc Godard, Breathless (1959)

Yönetmenliğini Jean-Luc Godard'ın yaptığ1 1959 tarihli Breathless filminde de (Görsel 5) bilimsel gerçekliğin kuantum alanına ilişkin temel ilke ve söylemlerin görüntü özelliklerine ilişkin önemli ipuçları elde edilebilir. Söz konusu filmde Marsilya'da ana karakter bir polis memurunu vurur, bir alandan geçer ve sonraki sahnede Paris'te olduğu görülür. Böylelikle montaj tekniği filmin zamansal yönüne vurgu yapan bir araç işlevi görür, görüntü hızlandırılır, izleyicinin devam eden sahnede gözleyeceği görüntü Kuleshov'un filminde olduğu gibi zamanda ileri ve geri giden bir algılama gerçekliğine dönüşür. Bu aynı zamanda izleyicinin gözlemlediği karakterin süperpozisyon durumunun gözlemci tarafından gözlemlenmesinin ardından tek bir olasılık dalgasına indirgenmesi gibi bir etkiye sahiptir. Schrödinger'in düşünce deneyi ve kuantum mekaniğinin Kopenhag yorumu ile ilgili paradoks, filmin montaj tekniği ile benzer bir etkiye sahiptir. Kutu içerisine yerleştirilen bir kedinin canlı ya da ölü olma durumunun yalnızca kutu açıldığında bilinebileceğini tanımlayan düşünce deneyinde olduğu gibi filmin ana karakterinin Marsilya'da mı yoksa Paris'te mi olduğu ancak sonraki sahnenin akışa dahil olması ile bilinebilir. Bu aynı zamanda Kopenhag yorumunun gözlemci etkisinin de doğrudan yansımasıdır, ana karakterin konumu gözlemcinin varlığına da bağlıdır. Görüldüğü gibi Lev Manovich'in atomistik yaklaşımında olduğu gibi görüntü farklı parçalara ayrılmış, ardından film yapımcısı tarafından aralarındaki mesafelerin kısaltılmasıyla yeniden bir araya getirilmiştir. Ancak bu kez söz konusu olan farklı sahnelerin Vertov sinemasında olduğu gibi üst üste yerleştirilmesi değil, yan yana getirilen görüntülerden oluşan dizinin aralarındaki mesafelerin kısaltılması ya da geçiş sürecine etki eden (süreci yansıtan) karelerin ortadan kaldırılmasıdır.
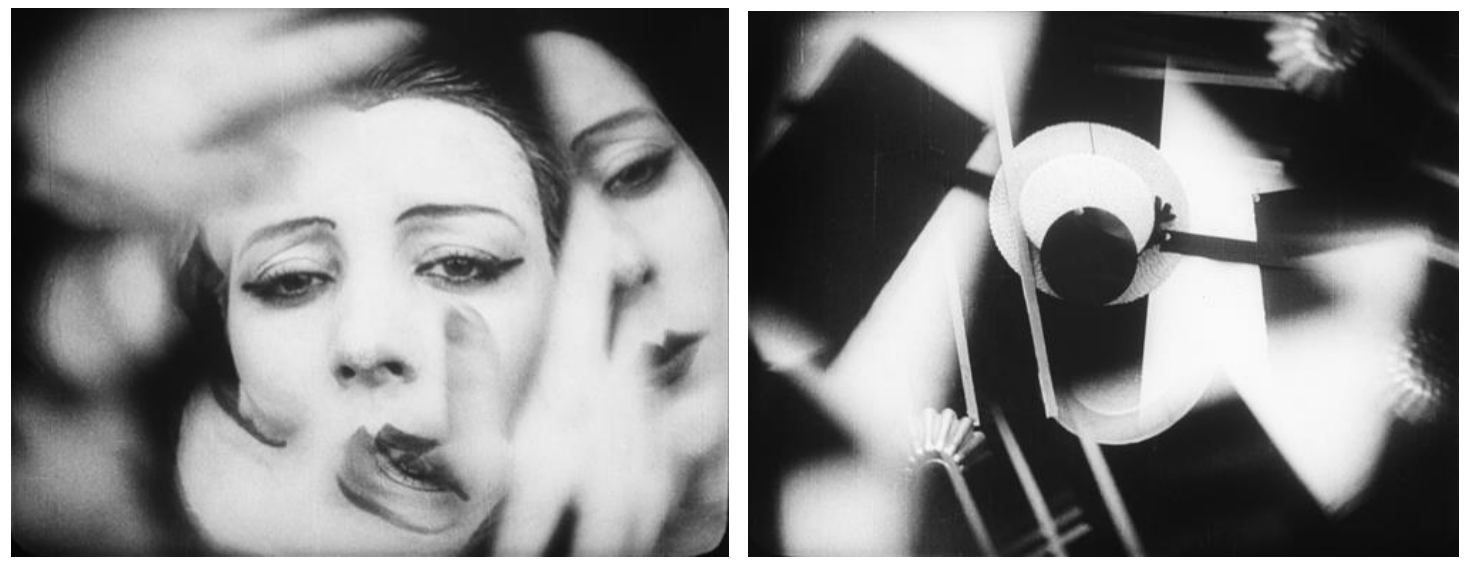

Görsel 6-7. Fernand Leger, Dudley Murphy, Ballet Mécanique (1924) 
Fernand Leger'in Dudley Murphy ile yönetmenliğini üstelendiği 1924 yapımlı deneysel film Ballet Mechanique'te (Görsel 6-7) görüntü birbirinin üzerine yerleştirilmiş sahneler yoluyla elde edilir ve Rodchenko'nun fotomontajlarında yaratılan etki sinemaya uyarlandığında eylemin zamansal olarak hızlanmasına olanak sağlar. Bu yöntem aynı zamanda fütüristlerin mekanikleşen estetik dilinin sahneye uyarlanmış biçimi olarak da yorumlanabilir. Fütürist sanatçıların iki boyutlu yüzey üzerinde yarattıkları hareket, ses ve gürültünün, "makine çağına uygun bir sanat yaratılması gerektiğini" vurgulayan söylemlerinin sinema üzerinde hem biçimsel olarak hem de içeriksel olarak bir araya getirildiği görülmektedir (Joyce, 2003: 394). Makinaların hareketi, tekrar eden insan eylemleri ile bir araya gelir, nesneler gerçek biçimlerinden uzaklaştırılarak ya da nesnel gerçekliklerinden soyutlandırılarak, sahneler nesnel anlamin ötesine, göstergesel anlama taşınır (Ünal, 2016: 2). Ballet Mechanique, gene kuantum mekaniğinin Kopenhag yorumu ile ilişkilendirilebilecek biçimsel düzenlemeye sahiptir. Gözlem yapıldığında (film hareketlendirildiğinde) fotoğraf karelerinin süperpozisyon durumları ortadan kalkar ve zamansal süreklilik ile birlikte dalga fonksiyonlarından birine indirgenir. Görüntü (aynı imgenin farklı olasılık konumları) incelenen filmlerde olduğu gibi atomistik yapılarına ayrılır -ancak burada üst üste ya da yan yana yerleştirilen görüntüler farklı imgeler ya da nesneler değildir- yeniden bir araya getirilir ve düzensiz bir kompozisyon (görüntü) elde edilir. Burada kullanılan montaj Vertov sinemasında olduğu gibi farklı görüntülerden oluşmaz, aynı görüntünün farklı anları bir araya getirilir ve karmaşık bir düzen/düzensizlik yaratılır.
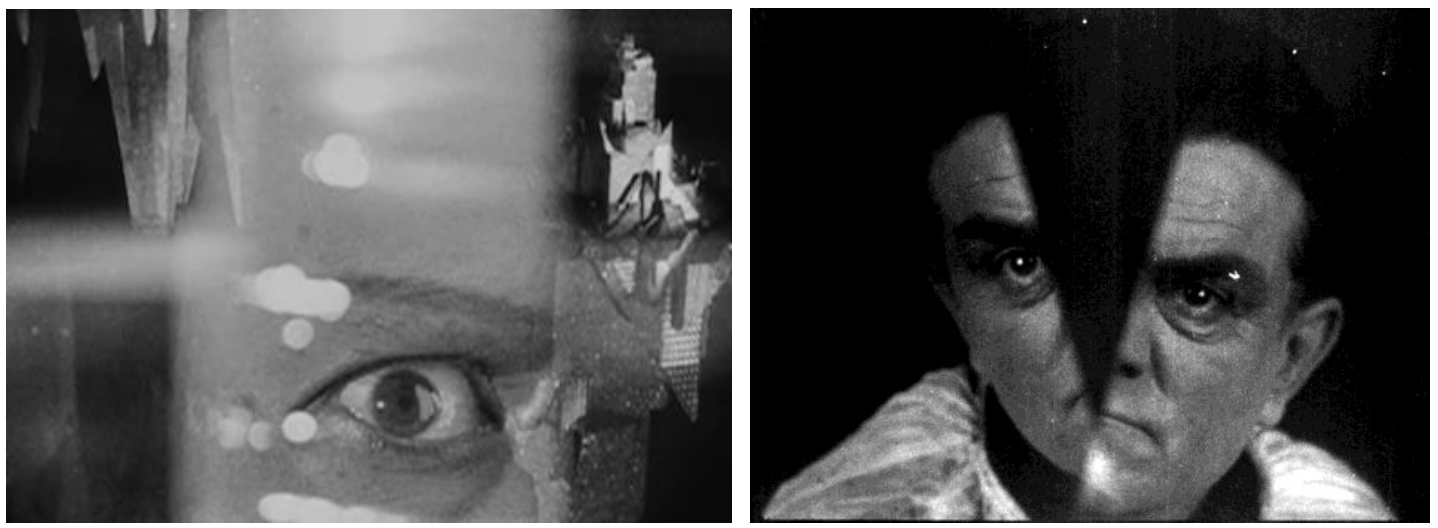

Görsel 8-9. Germaine Dulac, La Coquille et le Clergyman (Kabuk ve Rahip) (1928)

Benzer görüntü estetiği, Germaine Dulac'ın 1928 yapımı La Coquille et le Clergyman (Görsel 8-9) filminde de söz konusudur. Bu kez gerçeküstücü sanat eğiliminin peşinden ilerleyen kurgu, nesnel gerçekliği Mekanik Balet (Ballet Mécanique)'te olduğu gibi aynı sahne üzerinde (aynı zamansal süreklilikte) parçalarına ayırır ve bu parçaların hareketli yapısına vurgu yaparak yeni bir görüntü estetiği yaratır. Aynı figür ya da nesne görüntüsü parçalanmış ve gene aynı sahnede bu parçalar karmaşık bir düzenleme içerisinde bir araya getirilmiştir. Böylelikle çoklu algı perspektifleri ve alımlayıcının (izleyicinin) duyumuna göre değişen olasılık / gerçeklik yorumu elde edilmiştir.

Benzer etki 1926 yapımlı Hans Richter'in yönetmenliğini yaptığı FilmStudie (Film Study)'de de (Görsel 10-11) görülür. “(...) doğal ve soyut biçimler arasında herhangi bir çelişki olmadığını belirten Richter, FilmStudie'nin yaşanılan dünyanın bir parçası olarak soyut formlar geliştirdiğini ifade etmiştir" (Mekas, 1957: 5; Suchenski, 2009). Film boyunca insan yüzleri, yüzen göz bebekleri, soyut formlar birbiri üzerine yerleştirilerek, her bir fotoğraf sahnesi değişen yoğunluktaki işınlarla bir araya getirilmiş ya da sahneler birbiri içerisinde eritilmiştir. Bu yöntem, hem Fernand Leger'in Ballet Mecanique hem de Man Ray'ın 
1926 tarihli Emak Bakia filminde (Görsel 12-13) kullanılan montaj tekniğinin benzeridir ve incelenen tüm filmlerde olduğu gibi görsel algı birden çok sahneyi aynı anda takip etme imkanına sahip olurken, aynı zamanda bu yaklaşım izleyicinin bilişsel sınırlarını da zorlar.
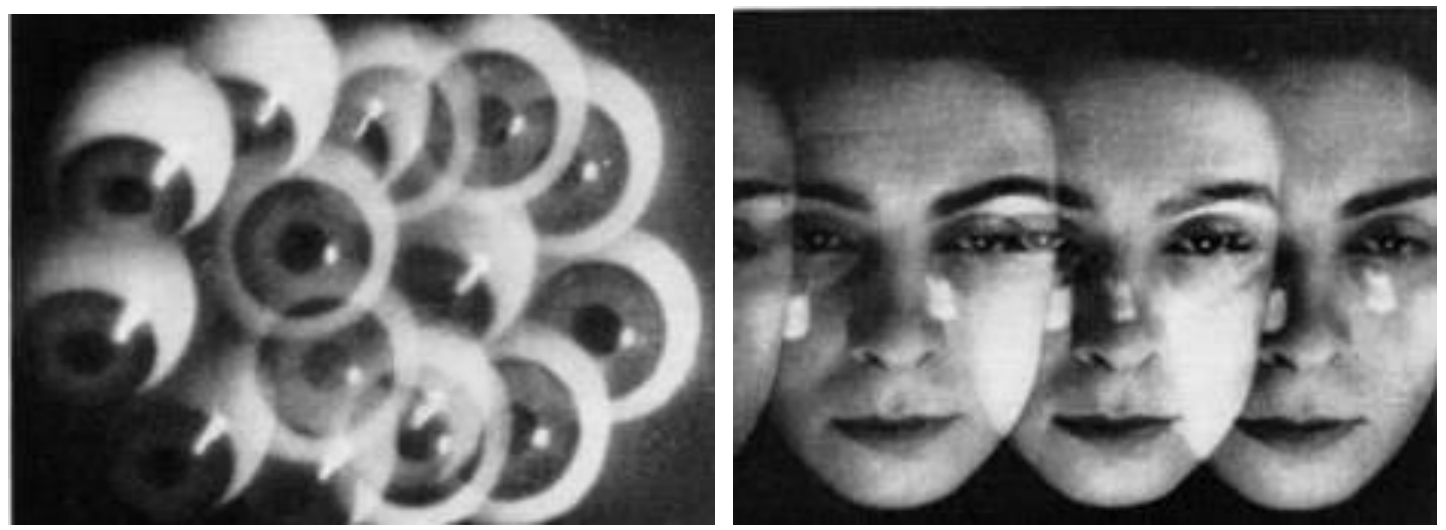

Görsel 10-11. Hans Richter, FilmStudie (Film Study) (1926)

Bununla birlikte bilimsel gerçekliğin kuantum alanına ilişkin göstergeler analiz edildiğinde, kuantum dolanıklık ilkesinin hem Fernand Leger'in filminde hem de Hans Richter'in filminde yansımalarına ulaşılır. Bu ilkeye göre iki benzer parçacık eşzamanlılık özelliğine sahiptir, farklı konumlarda ve çok uzak mesafelerde olsalar dahi birinde yaşanan bir durum değişimi diğerinde de benzer bir değişime neden olur. Bu parçacıklar arasındaki etkileşim ışık hızından daha hızlı bir iletişime sahiptir ve bu ilke göreliliğin en büyük problemi olarak Einstein'ın ışık hızından daha hızlı bir şey olamaz görüşünü reddeder. Benzer şekilde incelenen filmlerde de farklı görüntülerin (parçacıklar olarak düşünüldüğünde) birbirleriyle etkileşimde olduğu, aynı sahnede gözlemlenen tüm imgelerin değişen koşullarda aynı değişimi deneyimlediği (örn. sağa doğru akan bir sahnede tüm imgelerin aynı yöne doğru dağılması gibi) görülmektedir. Bu imgeler (örn. göz bebekleri ya da insan yüzleri) nesnel dünyadaki gerçekliklerinden koparılıp bir araya getirilmiş ve birbirleriyle ilişkilendirilerek aralarındaki bağlantı gözlemcinin varlığı ile tamamlanmıştır.
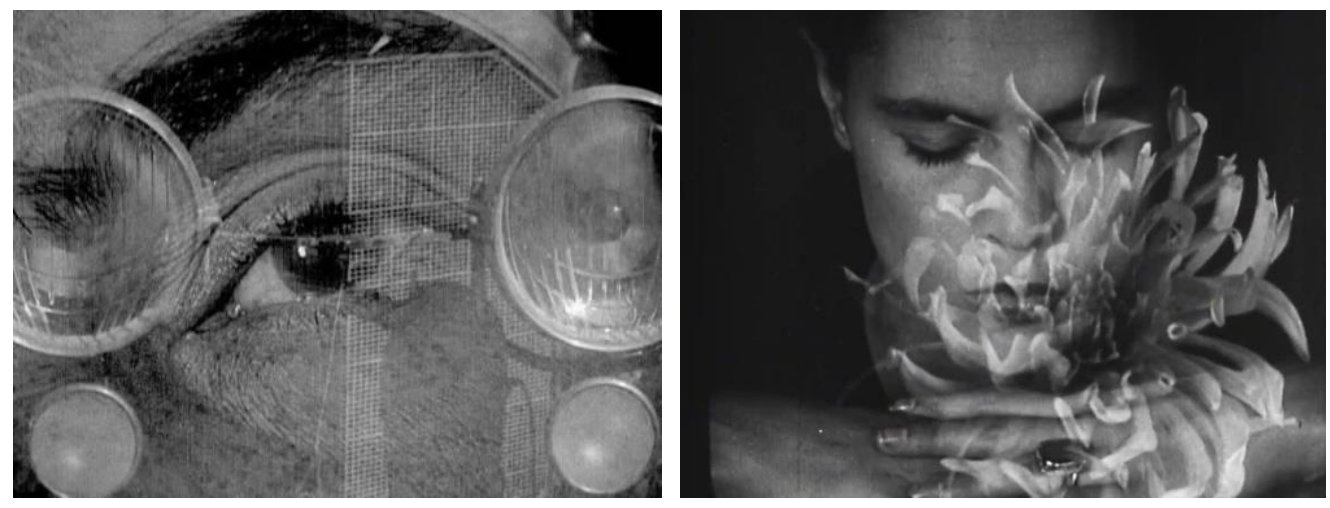

Görsel 12-13. Man Ray, Emak Bakia (1926)

Sinematografik montajın görsel verinin üst üste bindirilmek yerine yan yana getirilerek düzenlendiği formu incelendiğinde; sinema tarihinin ilk soyut filmi olarak tanımlanan ve 1923 yılına kadar Viking Eggeling, Tristian Tzara ile sayısız kez yeniden üretilen Richter'ın Rhythmus isimli filmi (Görsel 14) düz montajın kullanıldı̆̆ı en önemli avangard yapımlardandır. Dada gösterilerinde sergilenen bu filmlerinde Richter; "kare, dikdörtgen, üçgen, daire gibi geometrik formları; ritim oluşturacak tekrarlarla ve siyahbeyaz kontrastlı̆̆ından yararlanarak bir araya getirmiştir" (Foster, 1998: 84-86; Yılmaz, 2011: 
4). Bu yaklaşım aynı zamanda Mondrian'ın nesnel gerçekliği basit geometrik formlara indirgediği kompozisyonlarındaki görüntü estetiği ile de örtüşmektedir. Bu aynı zamanda Richter'in Film Study'sinde kullandığı tekniğin geometrik formlara indirgenmiş halidir (bu kez bilinen imgeler yerine bilinmeyen formlar zamansal sürekliliğin parçası haline gelir).
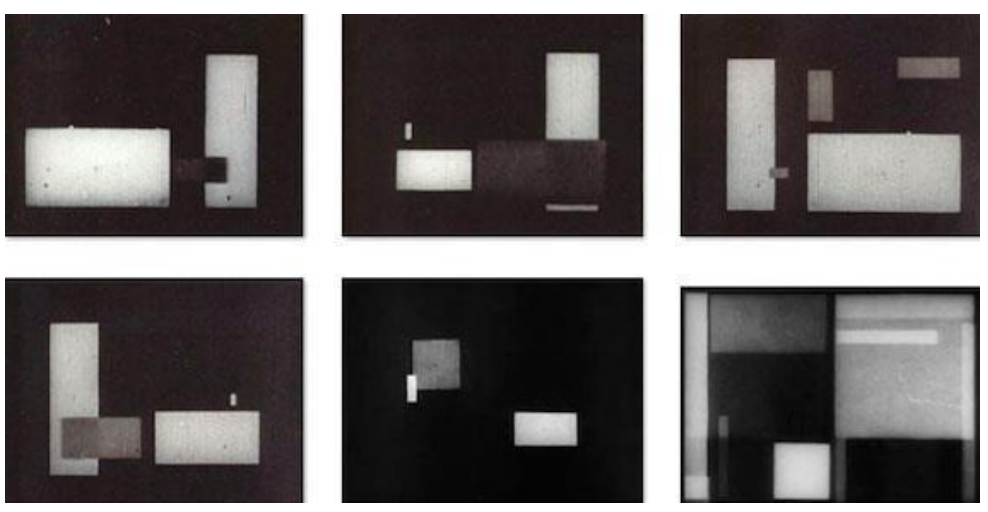

Görsel 14. Viking Eggeling, Tristian Tzara, Hans Richter, Rhythmus 21 (1923)

Bununla birlikte kuantuma ilişkin temel kavramların görüntü niteliklerine bakıldığında farklı sahnelerde aynı formun farklı büyük-küçük ilişkilerine yer verilmiş olması ancak değişen sahnelerin her birinde aynı formun yer alması kuantum dolanıklık kavramının ilişkiselliğine götürdüğü gibi, Heisenberg'in belirsizlik ilkesine de (bir parçacığın aynı anda hem momentum hem de konumunun tam ve doğru olarak tespit edilemeyeceği) ulaşılabilir. Her bir sahnenin değişen görüntüsü geometrik formun yapısı ve büyüklüğüne dair izleyicinin tahmin edebilirliğini ortadan kaldırır, tam bilinebilirlik yerine olasılık dalgasını getirir. Aynı zamanda salt biçimsel formu ile kutu içerisinde yer alan ve canlı mı ölü mü olduğu bilinemeyen Schrödinger'in kedisi analojisine de ulaşılabilir. Bununla birlikte aynı imgenin farklı boyutlarda görüntüsünün aynı sahnede birbiri üzerine yerleştirilmiş montaj dili de kuantum fiziğinin Kopenhag yorumu ile ilişkili çoklu evren modeline referans gösterilebilir. Her bir sekans birbirleriyle ilişkili farklı evrensel boyutların temsilleri gibi algilanabilir ve her bir sahnede yer alan formun konumlarının ve momentumlarının (sahnedeki hareketlerinin) farklı oluşu da gene bu ilişkilendirmenin yapılmasına olanak tanir.

Deneysel sinema tarihinde benzer bir biçim dilini kullanan diğer önemli yapım, Viking Eggeling'in 1922 tarihli Symphonie Diagonal isimli filmidir. Richter'ın düz montaj kullanımı ile aynı karakterde soyut geometrik şekillerden oluşan film, deneysel ve avangard sinema tarihinde çığır açan bir yapım olmuştur. Bu kez geometrik formlar yerini dairesel oluşumlara ve sarmal optik illüzyonlara bırakmıştır ancak yine de ortaya çıkan çoklu algı durumları kuantumun çoklu evren düşüncesi ile ilişkilendirilebilir. 


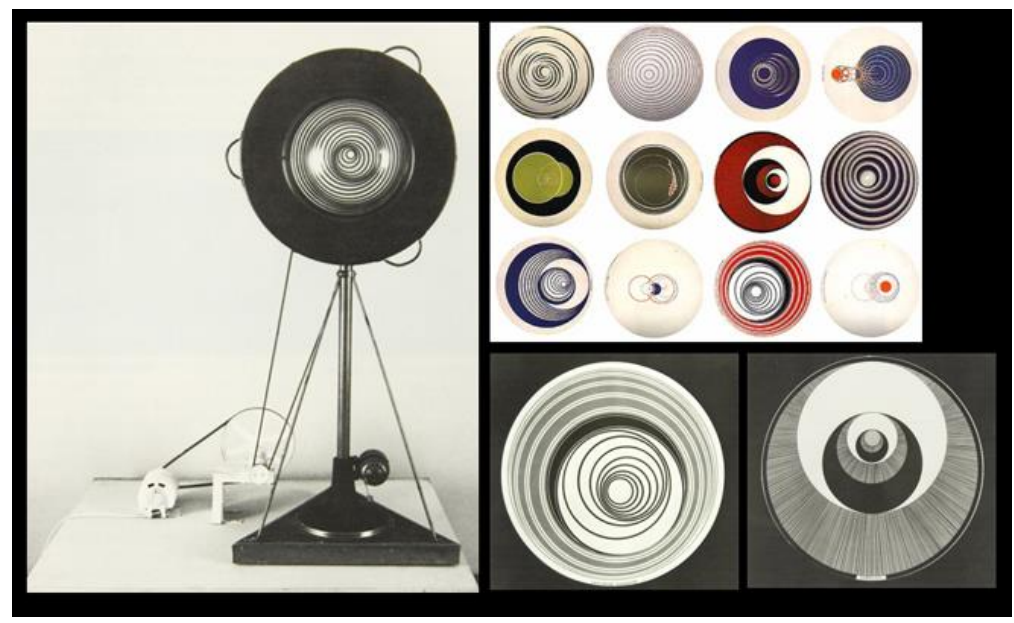

Görsel 15. Duchamp, Anemic Cinema (1926)

Marcel Duchamp'in Anemic Cinema isimli filmi de (Görsel 15) Eggeling'in sinemasında olduğuna benzer bir karaktere sahiptir. Nesnel gerçeklik önce atomik parçalarına (geometrik formlara) ayrılır, daha sonra ekran üzerinde yeniden bir araya getirilir. Fotoğraf karelerinin yan yana getirilerek eylemsel sürekliliğin sağlandığı filmde dokuz dönen optik görüntü yer alırken, zihinsel bir geri dönüşün ve sanatın bu dönüşün egemenliğine girissinin de yansımasıdır. Duchamp'ın 1926 tarihli avangard filmi Anemic Cinema ile yaratmak istediği etki; "Jasper Johns'un bir zamanlar 'dilin, düşüncenin ve vizyonun birbiri üzerinde hareket ettiği alan' olarak adlandırdığı şeyi yaratmak"tır (Anonim, 2011). Psikolojik etkilerin de yer aldığı filmin 1960'larda bir yanılsama alanı olarak ortaya çıkan optik sanatın da ilk örneklerinden biri olduğu görülür. Kuantumla ilişkilendirilebilecek referans noktaları incelendiğinde, öncelikle Einstein'ın zaman-mekanına ilişkin zamansal gerçekliğin ön planda olduğu görülür. Bununla birlikte kuantum dolanıklık kullanılan formun yapısal ve etkileşimli yönü ile vurgulanır (hareket halindeki sarmalın bir noktasında yaşanan bir sapma bütün olarak görüntünün yapısında değişime neden olur).

$\mathrm{Bu}$ yaratımların öncü sinema örnekleri olarak anılmasının temel nedeni, 1920'lerde yeni teknik ve olanaklar geliştikçe sinemanın tiyatronun biçimsel dilinden kurtularak sanatın avangard akımlarının etkisinde kendi yeni gerçekliğini yaratma yolunda ilerlemesinden kaynaklanmaktadır. Ünal'a göre; "Sinemaya özgü olan görüntüleri "yineleme" imkanı, nesnelerin ritmik bir dizisini yaratır ve görüntünün nesnel anlamını eritip, soyut anlamını vurgular" (2016: 2). Böylelikle sinemaya özgü yeni bir dil yaratılır (aslında bu dil sinema ile sınırlı değildir, görsel sanatların tüm alanlarında yeniden yorumlanır) ve düşünsel sürecin aktarılması yolunda yaratıcının önüne yeni ifade olanakları sunar. Benzer etki Hans Richter'in 1947 yapımlı ve Man Ray, Marcel Duchamp, John Cage, Max Ernst, Fernand Leger ve Alexander Calder gibi avangard ve sürrealist sanatçıların yazar ve yönetmen koltuğunda oturduğu Dreams That Money Can Buy isimli filmde de söz konusudur. Bir oda içerisinde yer alan kahraman bir aynada kendisini seyrederken aklının içini okuyabileceğini farkeder ve eğer kendi içine bakabiliyorsa bunu başkaları üzerinde de uygulayabileceğini düşünür. Böylelikle oda içerisinde hayalkırıklığı yaşayan ya da nevrotik insanlara hayali rüyalar satmaya başlar. Bu rüyalar boyunca sahneler birbiri üzerine yerleştirilir, montaj tekniği hem düz hem zamansal olarak bir arada yer alır. Bununla birlikte sürrealist üslup içerik olarak izleyiciye yansitılırken, makinelerin statik hareketi ile kesintiye uğrayan ve birbiri içerisine geçen sahneler fütürist manifestoya da gönderme yapar.

Paul Thomas Anderson'un yönetmenliğini yaptığı 1999 yapımı Magnolia filminde de (Görsel 16) Kuleshov sinemasında ve Godard'ın Breathless filminde olduğuna benzer bir 
montaj tekniği kullanılmıştır. Farklı imgeler, birbirinden bağımsız figürler, farklı konumlarda yaşanan birbirinden bağımsız olaylar arka arkaya yerleştirilmiş ve birbirleriyle ilişkilendirilmiştir. Ölmek üzere olan bir baba, bir bakıcı, babanın kaybolmuş ünlü oğlu, aşık bir polis, dahi bir çocuk, bir sunucu ve bir kız filmin kurgusu içinde aynı günün farklı sahnelerinde konumlandırılmıştır. Bununla birlikte sahneler ileri geri geçişlerle izleyiciye aktarılırken filmin sonunda birbirlerinin hayatlarındaki bağlantılar yavaş yavaş ortaya çıkarılmış ve izleyici tarafından anlamlandırılan bir ilişkisellik elde etmiştir. Nesnel gerçekliğin sinematografik perspektife yansımasındaki bu yaklaşım kuantum alan teorisinde parçacıkların dolanıklılık ilkesine ilişkin önemli bir referansa gönderme yapar. Filmde yer alan her bir figürün seçim ve eylemlerinin sonuçlarının birbirleri üzerinde etkisi, fiziksel gerçekliğin parçacıklar arasındaki kesin ilişkilerin yerine ara düzenlerin ele alındığı John Bell teoremi ile koşut ilerler. Filmin başından sonuna kadar işlenen olay örgüsü de bu ara düzeni ele alır, en sonunda yapılan seçimlerin birbirlerinin hayatları üzerindeki etkisi (bir parçacığın diğeri ile bağlantılı olması) izleyicinin görünür algısına taşınır.

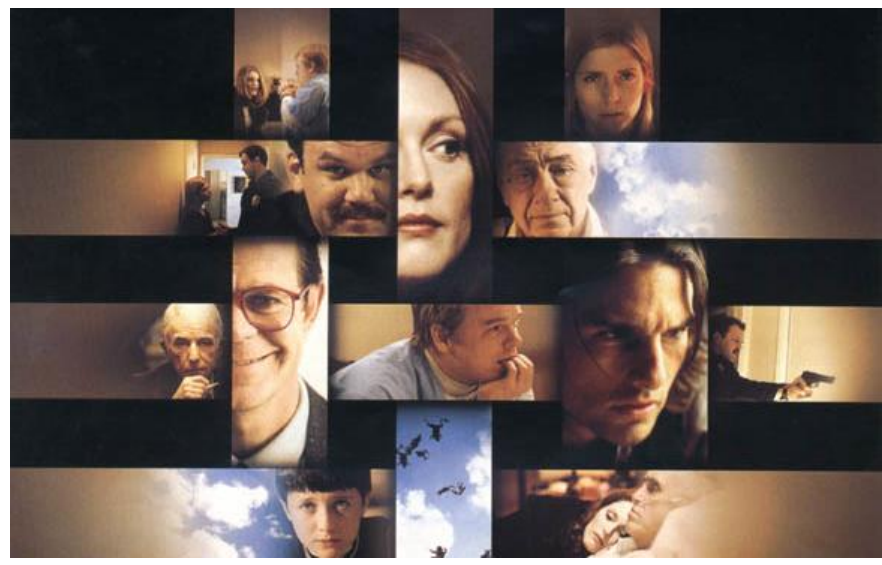

Görsel 16. Paul Thomas Anderson, Magnolia (1999)

$\mathrm{Bu}$ doğrultuda genel olarak değerlendirildiğinde bu filmlerde yer alan montaj kullanımı ve onun getirdiği teknik özellikler ile (örneğin bir göz bebeğinin ait olduğu figürden ayrılarak sahnenin farklı bir yönüne doğru kayması ve onun yerini alan beyaz görüntü) farklı imgelerin bir arada varlığından (kullanımından) doğan karmaşık bir düzen yaratılır, bu aynı zamanda çoklu bir referans sistemine gönderme yapar ve izleyicinin bu referans çerçeveleri içerisinden kendi algısal gerçekliğine ulaşmasına olanak tanınır. Böylelikle aslında klasik fiziğin savunusu olan tek bir nesnel gerçekliğin var olduğu ve paradigma kapsamında tek bir referans noktasının tanımlandığı düşüncesi yerini kuantumun çoklu perspektiflerine, bilincin etkisine, gözlemcinin konumuna ve bakış açısına göre değişen gerçeklik çeşitlemelerine ve bütün olarak kuantum fiziğinin temel ilke ve söylemlerine bırakır. Kuantum fiziğinin belki de en soyut teorisi olan çoklu evren düşüncesi de sinema ve fizik arasında bu filmler yoluyla kurulan ilişkinin yansımasıdır. Farklı imgeler, farklı bakış açıları, farklı montaj teknikleri ve farklı ekran görüntüleri Schrödinger'in olasılık dalgasına doğrudan gönderme yaptığı gibi, bunun yanında üzerinde durulması gereken bir diğer nokta; izleyicinin ekrandan yansıyan görüntüden yalnızca birini seçmek zorunda kalmaması (sadece anlık görüntü zihinde parçalanmış bir estetiğin oluşumuna neden oluyor), aynı anda birden fazla zamansal gerçekliği gözlemleyerek olasılıkların her birini kendi olası gerçeklikleri ile var ediyor olmasıdır. Elbette kuantum alanına ilişkin temel yaklaşımların ya da "çoklu evren", "paralel dünyalar", "kuantum dolanıklık" gibi daha soyut gerçeklik modellerinin sinemanın kendi özgül anlamı içine sokularak ilişkilendirilmesi 1990'lardan sonra doğrudan onu konu alan filmlerde olduğu gibi (paralel dünyalarda aynı 
anda yaşanan olaylar, varoluşsal durumların kaderle ilişkili olasılık anları vd.) basit aktarım biçimlerine ve bağıntısız gerçekliklere indirgenmesi söz konusu bilimsel gerçekliklerin kendi özgül anlamlarından uzaklaşmasına neden olur. Ancak yapılmakta olan ilişkilendirme bilimsel ilerlemenin (bilim alanında yaşanan bir gelişmenin) evrensel gerçekliğe kazandırmış olduğu olasılık dünyasının sanatın yaratıcılık boyutuna etkisinin gözlemlenmesidir.

\section{Bilimsel Gerçekliğin Sinemaya Tematik Yansıması (Konu Bă̆lamında)}

Buraya kadar incelenen çalışmalar bilimsel gerçekliği doğrudan konu almayıp sinema felsefesinin dolaylı gözlemlenimi ya da daha yoğun olarak biçimsel kurgunun yorumlanışı ile kuantum gerçekliği ile ilişkilendirilebilen çalışmalardır. Bu çalışmaların analizi elbette kesin veriler olmayıp yapılan incelemeler bireysel gözlemler ve çıkarımsal sonuçlardan öteye geçmez. Ancak bu filmlerin kurgusal gerçeklikleri ve teknik sunumlarının kuantum alanına ilişkin temel ilkelerle benzerlikleri ve birbirlerine koşut fiziksel gerçeklikleri yapılacak daha kapsamlı analizler için aydınlatıcı ve ilham vericidir. Biçimsel olarak incelenen deneysel sinema örneklerinin, bu başlık altında konu bakımından incelenen çalışmalardan daha araştırmaya açık olmasının bir diğer nedeni de, bu ikinci kategoride incelenen filmlerin bilimsel gerçekliği doğrudan konu almasına karşın uygulamada bağlam dışına çıkmasından ve estetik olduğu kadar beğeni kaygısı ile popüler kültür etkisinde bilimsel kuram ve ilkeleri özgün anlam ve amaçlarından uzaklaştırmasından kaynaklanmaktadır. Ancak yine de kuantum fiziğinin ve genelde kozmolojik gerçekliğin konu edilmesi bakımından önemli film örnekleridir.

Bu kapsamda öncelikle yönetmenliğini Eric Bress ve J. Mackye Gruber'in üstlendiği Butterfly Effect (2004) filmi (Görsel 17) incelendiğinde, Einstein'in zaman-mekana ilişkin görelilik ilkesi, zamansal dördüncü boyut, evrenin bükümlü teorisi gibi önemli bilimsel literatürün sinematografik düşünceye dahil edildiği, yeniden kurgulandiğı ve film diline çevrildiği görülmektedir. Hikayenin ana karakteri olan genç bir adamın geçmişe yolculuk yapabildiğini keşfetmesi ve olayları değiştirme çabalarının konu alındığı filmde, her değişikliğin hem kendi hayatını hem de etrafındaki diğer insanların hayatını etkilemesi söz konsudur. Elbette bilimsel gerçeklik açısından zaman yolculuğu söz konusu değildir ancak yapılan seçimlerin ya da değişen olayların başkaları üzerinde de önemli etkilere neden olması kuantum dolanıklık (parçacıkların birbirleri ile etkileşimli olması ve geniş mesafelerde birbirlerini etkileyebilmesi) ilkesinin doğrudan açıklamasına götürür. Gene filmin söz konusu sahneleri (farklı seçimlerin farklı olaylar dizgesini başlatması) Schrödinger'in düşünce deneyinin bir sonucu olarak olasılık dalgası ve süperpozisyon durumlarına da referans yapmaktadır. Yapılan her bir seçim farklı olasılıklar içinden bir ayıklamayı gerektirir (kutunun açılması ya da kapalı kalması) ve böylece dalga fonksiyonu çökerek farklı olasılıklardan biri (kedinin ölü ya da canlı olma durumu) ortaya çıkar.

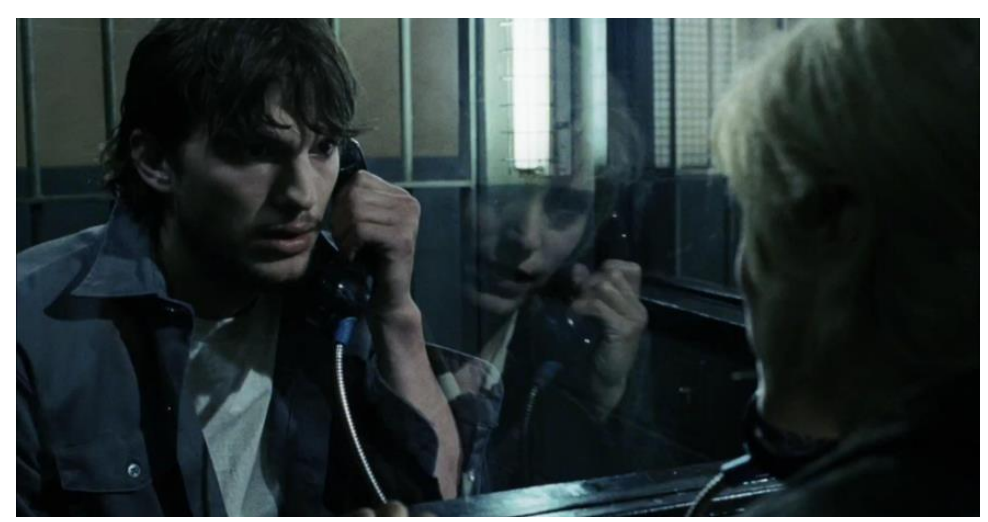

Görsel 17. Eric Bress, J. Mackye Gruber, Butterfly Effect (2004) 
Kuantum fiziğinin temel ilke ve teorileri ile ilişkilendirilebilecek bir diğer yapım 2008 yılında gösterime giren Fringe dizisidir (Görsel 18). Farklı bölümlerinde ve farklı sahnelerinde Jules Verne'in eserlerinden Arthur Clarke'ın romanlarına, Aldous Huxley ve Asimov'dan Star Trek ve Back to Future filmlerine kadar pek çok göndermenin yer aldığ dizinin genel olay örgüsü paralel evrenler üzerine kurulmuştur.

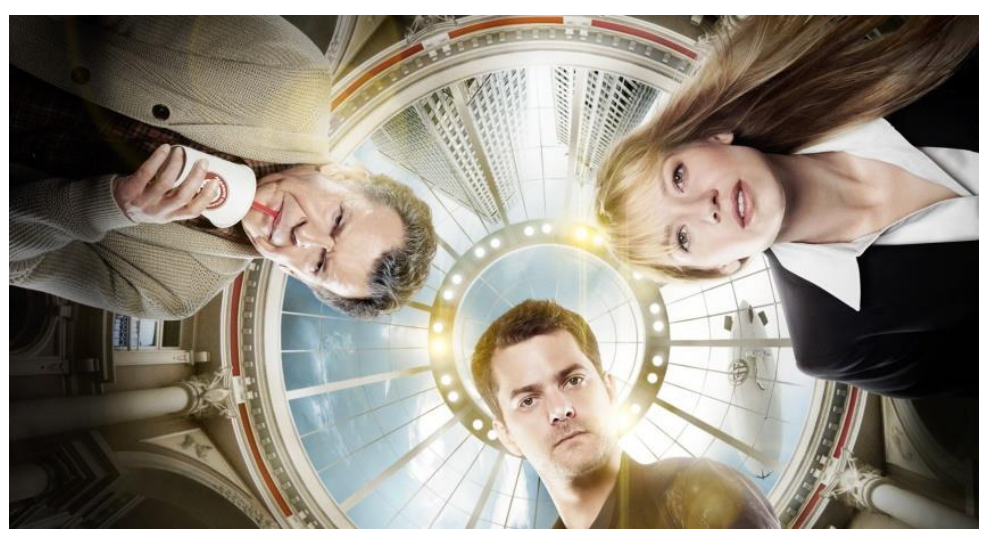

Görsel 18. I. I. Abrams. Alex Kurtzman ve Roberto Orci. Fringe (2008-2013)

Daha önce de belirtildiği gibi paralel evren ya da çoklu evren teorisi bilimsel gerçeklik içerisinde kuantumun Kopenhag yorumu ile ilişkili sicim teorisine koşut olarak geliştirilmiş bir teoridir. Ancak kanitlanmamış söz konusu düşünce bir olasıllk olarak bu filmlerde ve dizilerde yer alan kurgusallıktan oldukça uzak bir gerçekliğe de sahiptir. Bunun en önemli nedeni söz konusu sinema örneklerinin paralel evren düşüncesini aynı anda yaşanan birbirinden bağımsız ama birbirinin aynısı evrenler olarak tanımlamasından kaynaklanmaktadır. Oysa bunun bir teori olmasının yanında söz konusu teorinin temelini oluşturan düşünce Schrödinger'in deneyi ve John Bell teoremi ile ilişkili olasıllk dalgasına dayanır. Süperpozisyonun gözlem yapıldığında her iki olasılıktan birine indirgenmesi yalnızca yaşanılan zamansallık içerisinde gerçekleşen bir olaydır. Ancak bu teoriye göre başka bir evrende bu olasılıklardan diğeri de söz konusu olabilir. Böylelikle her bir olasılık yeni evren yaratır ve içinde yaşanılan evren paralel evrenlerden yalnızca biri konumuna taşınır. Yönetmenliğini Mike Cahill'in yaptığ1 2011 yapımı Another Earth filminde de (Görsel 19) benzer bir konu işlenir. Paralel bir dünya, görülür, erişilebilir, iletişim kurulabilir bir gerçeklik olarak tanımlanır ve karakterler paralel gerçeklikte de benzer yaşamsal özellilklere sahiptir. Filmin sonunda her iki dünyanın kesişimi söz konusu olur ve her iki evrendeki kadın karakter aynı sahnede bir araya gelir. Elbette kuantum gerçekliğinde henüz kanıtlanmamış bir gerçeklik olarak ortaya atılan bir teori olan paralel evren düşüncesi ya da çoklu evren modelinde böyle bir birliktelik söz konusu değildir. Bununla birlikte her iki evrenin birbirleri ile kurdukları paradoksal ilişki (iletişim) simgesel olarak kuantum dolanıklık ilkesi ile ilişkilendirilebilir. Filmde kozmolojik bir gerçeklik olarak vurgulanan paralel dünya ile kurulan ilişki her ne kadar yaşanılan dünyada bir değişime neden olmasa da karşılıklı kurulan bağ parçacık fiziğine referans olarak görülebilir. 


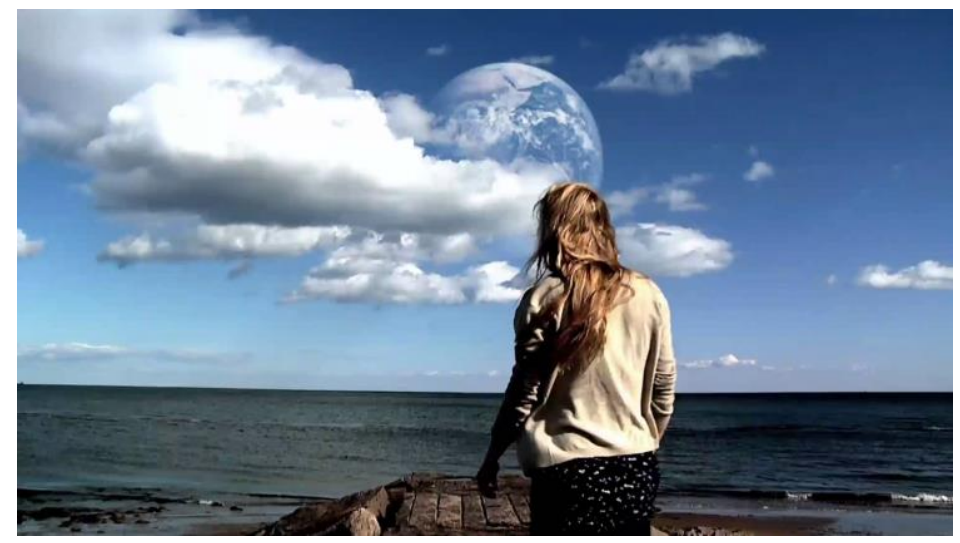

Görsel 19. Mike Cahill, Another Earth (2011)

Benzer kurgusal gerçeklik (zaman yolculuğu ve paralel evren) yönetmenliğini Baran bo Odar'ın üstlendiği Dark dizisinde de söz konusudur (Görsel 20) Dizide bir nükleer santralde gerçekleşen bir patlama bir tünelin oluşmasına neden olmakta ve bu tünel yoluyla geçmişe ve geleceğe yolculuk olanaklı kılınmaktadır. Einstein'ın "geçmiş, şu an ve gelecek arasındaki fark, inatçı bir illüzyondan ibarettir" sözleriyle zaman paradoksuna gönderme yapılarak başlayan dizi gerçeklik ve yanılsama arasında hassas bir denge kurmuş olsa da yine de incelenen diğer sinema örneklerinde olduğu gibi bilimsel gerçekliğin popüler kültür tarafından kurgu gerçekliğe dönüştürülmesinden öteye geçmemektedir

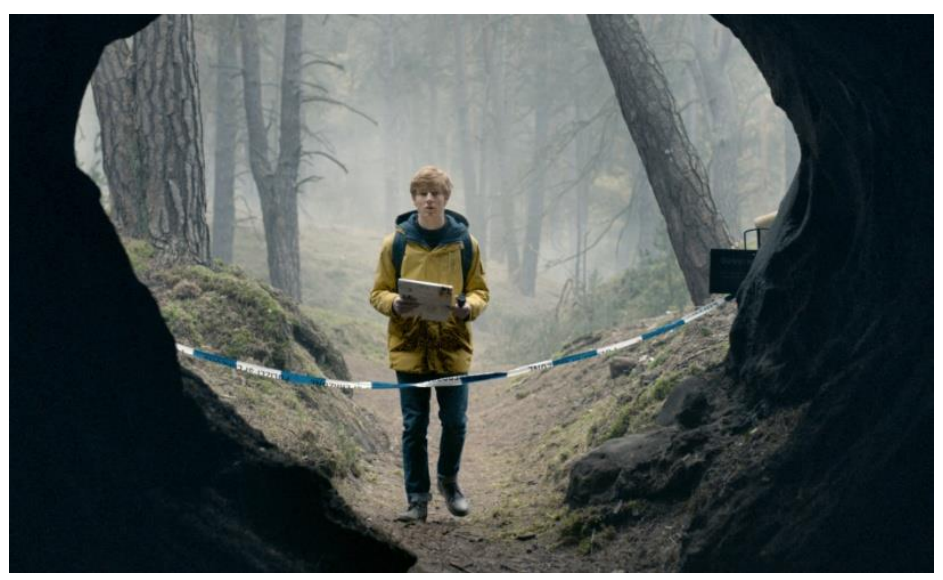

Görsel 20. Baran bo Odar, Dark (2018)

Bununla birlikte bilimsel gerçeklik açısından dizinin kurgusu yalnızca zaman yolculuğu ve paralel evrenlerle sınırlı değildir. Gerek açılan tünel gerekse diğer olaylar kozmolojik düzene ve karanlık madde (kara cisim) ile karanlık enerjiye ilişkin de kurgusal göndermeler de yapmaktadır (karanlık madde ışın yaymayan ya da elektromanyetik ışınları doğrudan algılanabilecek şekilde yansitmayan bir madde türüdür). Ancak elbette dizide yer alan gönderme diğer olgusal gerçekliklerde olduğu gibi maddenin ya da 1şımanın özgün anlamının yorumlamasıdır. 

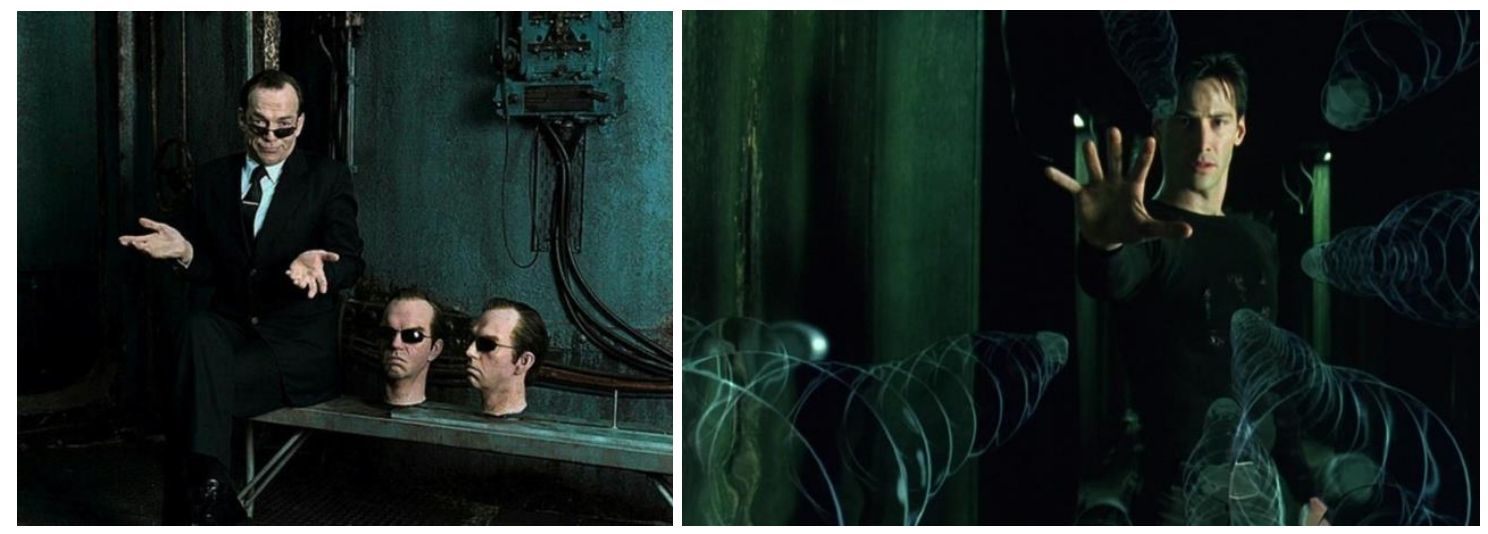

Görsel 21-22. Lana Wachowski, Lilly Wachowski, Matrix (1999)

Bilimsel gerçekliklerin ve özellikle kuantum alanına ilişkin temel ilkelerin doğrudan olmasa da içerik olarak konu edinildiği bir diğer film Wachowski kardeşlerin 1999 yapımı Matrix filmidir (Görsel 21-22). Filmin kurgusu yaşanılan dünya ile sanal dünya arasındaki olaylar üzerine kurulmuştur ve bu dünyalar arasında seçim kişilere bırakılmıştır. Gene paralel dünyalar, çoklu evren teorisi ve Heisenberg'in belirsizlik ilkesinden John Bell teoremine ve Schrödinger'in kedisine kadar birden fazla kuantuma ilişkin bilimsel yaklaşımin filmin bütününden ilişkilendirilebildiği görülmektedir. Ancak yine belirtildiği gibi bu ilişkilendirme yalnızca soyut bir kavramsal ilişkiden öteye geçmez, yalnızca dolaylı bir gönderme söz konusudur.

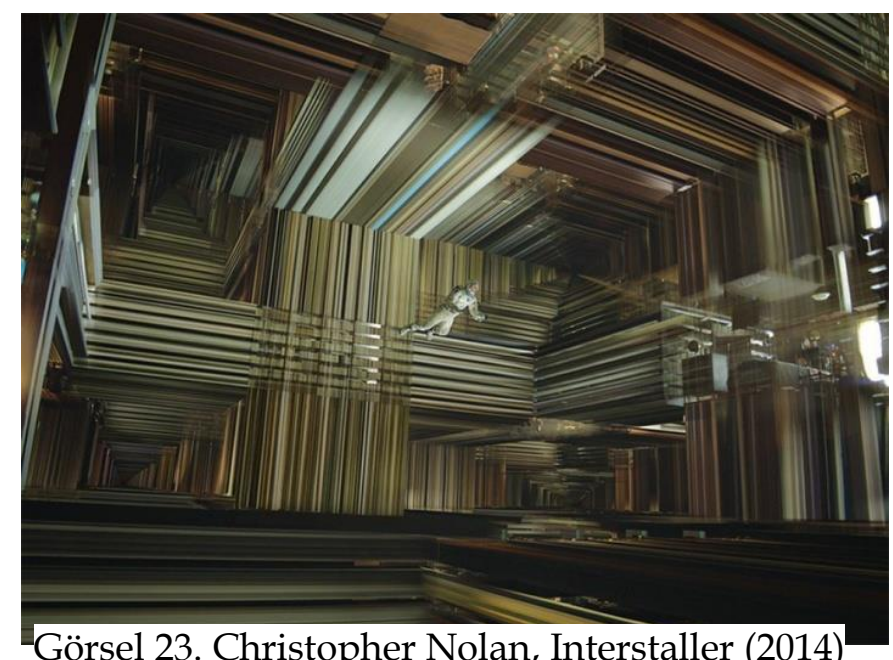

Son olarak Christopher Nolan'ın 2014 yapımı Interstaller filmine bakıldığında (Görsel 23), dünyadaki yaşamaya elverişsiz koşullar nedeniyle bir grup bilim adamının uzayda yeni bir yaşam alanı bulma çabası etrafında dönen bilimkurgu, incelenen diğer filmler arasında belki de bilimsel gerçekliğe en yakın kurgulardandır. Bunun bir nedeni teorik fizikçi Kip Thorne'un Noland'a danışmanlık yapmış olması ve gerek sahnelerin görselliğini gerekse olay örgüsünü bilimselliğe olabildiğince yaklaştırmış olmasıdır. Kozmolojik düzen, uzayın yapısına ve uzay yolculuğunun koşullarına yapılan önemli göndermelerin yanında, özellikle Einstein'ın görelilik ilkesine, zaman yolculuğuna, ikizler paradoksuna, solucan deliklerine ve uzay-zamana da referanslar söz konusudur. Bununla birlikte görelilik ilkesi ile tanımlanan hız değişiminin uzay-zamanda bir açı oluşu ile kinematiğin bir geometri oluşu da doğrudan filmin konusu olan bilimsel gerçekliklerdir. Doğrudan olmasa da kuantum dolanıklı̆̆a, 
Bohr'un tamamlayıcılık ilkesine ve Kopenhag yorumu ile olasılık dalgasına da önemli göndermeler söz konusudur. Özellikle ana karakterin daha filmin başında yapmış olduğu seçim doğrudan süperpozisyon ve olasılık ilişkisini öne çıkarır.

\section{Sonuç}

Görüldüğü gibi hemen her alanda yaşanan paradigma değişimleri birbirlerini hem etkilemiş hem de birbirleri üzerinde önemli etkilere neden olmuştur. Bilimsel gelişmeler gerek toplumsal yapıda yaşanan köklü değişimler gerekse düşünce sistemlerinde yaşanan başkalaşımın hem bir sonucu hem de nedenidir ve aralarındaki ilişki karşılıklı etkileşimli bir süreçtir. Bilim, felsefe ve sanat triyalektiğine bakıldığında da her birinin kendi içinde paradigmatik bir ilerleme düzenine sahip olduğu ve değişen paradigmalar kapsamında hemen her alanda yaşanan kaymaların yakın tarihlerde ve benzer yönelimlerde olduğu görülmektedir. Sinema tarihine bakıldığında da diğer alanlarda yaşan paradigma kaymalarının kesişim noktalarından beslendiği ve ilerleme düşüncesini gerek tematik olarak gerekse teknoloji bağlamında kapsamı içerisine dahil ettiği görülmektedir.

Bilim tarihinde örnekleme alınan paradigma olarak kuantum fiziği incelendiğinde, onun evrenin tanımlanmasına ilişkin temel ilke ve söylemlerinin gerek görsel sanatlar gerekse sinema alanında önemli bir referans çerçevesi olarak görüldüğü tespit edilmiştir. Bu ilişkiye bakıldığında Einstein'ın zaman ve mekana ilişkin göreli evren anlayışının zaman vurgusundan doğan ifade yöntemlerinin belirginleşmesine, kuantum dolanıklık, John Bell teoremi ve EPR paradoksunun sanatta etkileşim konusuna çağrışım yaptığına, Heisenberg'in belirsizlik ilkesinin hareket ve mekan çözümlemelerinde ritmik tekrarlara, Bohr'un tamamlayıcılık ilkesinin perspektifsel olmayan mekansal yerleştirmelere, Schrödinger'in kedisi düşünce deneyinin süperpozisyon ve olasılık ilişkisi ile çoklu algı durumlarına, Bohr'un Kopenhag yorumunun alımlayıcının duyumuna göre değişen gerçeklik algısına referans olduğu görülmektedir.

Sinematik düşüncenin bilimsel aklı yorumlama biçimlerine bakıldığında ise üç farklı yolun izlendiği ya da yorumlama yöntemi olarak belirlendiği görülür. Bunlar kuantum felsefesinden ve temel ilkelerinden yola çıkılarak üretilmiş filmler, kuantumun yeni gerçekliğinin teknoloji boyutunda sinemaya yansımaları ve alımlayıcı tarafından kuantum fiziği ile ilişkilendirilebilecek sinema örnekleridir. Her bir kategori başlı başına uzun bir araştırmayı gerektirmesine karşın, temel dinamikleri ile incelendiğinde kuantum alanının sinematik düşünceye yansımalarının tematik (konu bağlamında) yansımadan çok daha kapsamlı ve bilim sanat arasında kurulan bir köprü olabileceği anlaşılmaktadır. Bu köprü salt gözlem ve yoruma dayalı olma anlamında değildir, kurulan ilişki yoluyla farklı alanlarda paradigmaların kesişim noktalarındaki etkilenmelerinde görünür algıya taşınması ve duyumsanması açısından önemli bir girişimdir. 


\section{Kaynakça}

Anderson, P. T. (Yönetmen/Yapımcı). (1999). Magnolia (Manolya) [Sinema Filmi]. ABD: NewLine Cinema. Dizisi].

Abrams, J.J. \& Kurtzman, A. \& Orci, R. (Yapımc1). (2008-2013). Fringe [Bilimkurgu

Anonim (2011). Anemic Cinema: Marcel Duchamp's Whirling Avant-Garde Film. http:// www.openculture.com/2011/10/anemic_cinema.html (erişim: 08.09.2018).

Berger, J. (1993). Görme Biçimleri (Çev. Yurdanur Salman). İstanbul: Metis Yayınları. 2, 9-17.

Bordwell, D. (1972). "The Idea of Montage in Soviet Art and Film", Cinema Journal, 11,

Bress, E. E Gruber, J.M. (Yönetmen) \& Bender, C. \& Dix, A.J. \& Spink, J.C. (Yapımc1). (2004). Butterfly Effect (Kelebek Etkisi) [Sinema Filmi]. ABD: NewLine Cinema.

Cahill, M. (Yönetmen). (2011). Another Earth (Başka Bir Dünya) [Sinema Filmi]. ABD: Artists Public Domain. Film]. France.

Dulac, G. (Yönetmen). (1928). La Coquille et le Clergyman (Kabuk ve Rahip) [Deneysel

Duchamp, M. (Yönetmen). (1926). Anemic Cinema [Kısa Film/Deneysel Film]. Paris.

Eggeling, V. (Yönetmen) \& Tzara, T. (Yönetmen) \& Richter, H. (Yönetmen/Yapımc1). (1923). Rhythmus 21 (Ritim 21) [K1sa Film/Deneysel Film]. Paris.

Foster, S. C. (Ed.) (1998). Hans Richter, Activism, Modernism and the Avant-Garde. London: The MIT Press.

Godard, J. L. (Yönetmen) E Beauregard, G. (Yapımc1). (1959). Breathless (Nefes Nefese). [Sinema Filmi]. France: UGC.

Joyce, M. (2003). "Form: Montage" (Chapter 11), Jill Nelmes (Ed.), An Introduction to Film Studies. New York: Routledge.

Kuleshov, L. (Yönetmen) \& Hanjonkov, A. (Yapımc1). (1918). Engineer Prite's Project (Mühendis Prite'ın Projesi) [Deneysel Film]. Soviet Union: Khanzhonkov Company.

Klein, E. (2018). Kuantum Dünyasında Küçük Bir Gezinti. İstanbul: Bgst Yayınları.

Kıraç, R. (2012). Sinemanın ABC'si. İstanbul: Say Yayınları.

Leger, F. (Yönetmen) \& Murphy, D. (Yönetmen) \& Charlot, A. (Yapımcı). (1924). Ballet Mécanique (Mekanik Bale) [Kisa Film/Deneysel Film].

Mekas, J. (1957). “Hans Richter on the Nature of Film Poetry", Film Culture 3, No. 11, p.5

Manovich, L. (2002). "Avant-garde as Software", University of California. http://www.uoc.edu/artnodes/espai/eng/art/manovich1002/manovich1002.pdf (erişim: 09.04.2018).

Nolan, C. (Yönetmen) \& Thomas, E. \& Obst, L. \& Nolan, C. (Yapımc1). (2014). Interstaller (Yıldızlararası) [Sinema Filmi]. ABD: Legendary Pictures. 
Odar, B. b. (Yönetmen). (2018). Dark [Bilimkurgu Dizisi]. Almanya.

Özcan, R. E. (2016). "Man with a Movie Camera (yön: Dziga Vertov, 1929)", Yaşlı Kıta Avrupa: Avantgarde Cinematheque. https://filmhafizasi.com/yasli-kita-avrupaavantgarde cinematheque-ozel-dosya/2/ (erişim: 08.09.2018).

Richter, H. (Yönetmen). (1926). FilmStudie (Film Study) [Kısa Film/Deneysel Film].

Ray, M. (Yönetmen). (1926). Emak Bakia [Kısa Film/Deneysel Film]. France.

Rosen, P. (der.) (1986). Narrative, Apparatus, Ideology. New York: Columbia University Press.

Suchenski, R. (2009). "Hans Richter".

http://sensesofcinema.com/2009/greatdirectors/hans-richter/(erişim: 09.09.2018).

Tokdil, E. (2018). "Yeni Medya, Temel Bileşenleri ve Sanatın Değişen Estetik Dili", İletişim Kuram ve Araştırma Dergisi, Sayı 47, s. 167-190.

Ünal, Ç. (2016). "Ballet Mécanique (yön: Fernand Leger, Dudley Murphy, 1924)". Yaşlı Kita Avrupa: Avantgarde Cinematheque. https:// filmhafizasi.com/yasli-kita-avrupaavantgarde-cinematheque-ozel-dosya/2/ (erişim: 08.09.2018).

Vertov, D. (Yönetmen). (1929). Man with a Movie Camera (Kameralı Adam) [Deneysel Film/ Sessiz Film]. Soviet Union: VUFKU.

Wachowski, L. \& Wachowski, L. (Yönetmen). (1999). Matrix [Bilimkurgu Dizisi]. ABD: Warner Bross.

Yılmaz, S. (2011). "20. Yüzyıl Avangard Akımların Gelişim Sürecinde Sinema". Trakya Üniversitesi Sosyal Bilimler Dergisi. Cilt 13, Sayı 2, s. 371- 382. 